\title{
Passion and Power: Edwardian Censorship and E.F. Benson's Homoerotic Public School Novel David Blaize (1917)
}

\author{
Carol Naylor
}

\begin{abstract}
At school friendship is a passion. It entrances the being: it tears the soul. (Benjamin Disraeli, Coningsby)
\end{abstract}

It $t$ would appear, at the beginning of the twenty-first century, that there is a proliferation of discourses on men and masculinities, which also include issues around boys and literacy, boys and violence, and so on. As Lynne Segal puts it, 'men appear to be emerging as the threatened sex; even as they remain, everywhere, the threatening sex' (Segal 1997, Introduction). If there can be said to be a 'crisis in masculinity', then, according to Badinter and Kimmel, there have been at least two earlier crises involving the questioning of the meaning of 'masculinity' in countries undergoing ideological, economic or social changes' (Badinter 1995, pp.9-20 and Kimmel 1987 in Petersen 1998, p.41). Jeffrey P. Hantover takes up the question of anxiety around manliness at the turn of the twentieth century, when the English school novel, David Blaize was published. He claims that 'men believed they faced diminishing opportunities for masculine validation and that adolescents faced barriers to the very development of masculinity' (Hantover 1978, p.185). Connell also notes the way that ideologists of patriarchy struggled to control and direct the reproduction of masculinity. He asserts that there was 'a fear that boys would be feminized through too much influence by women' (Connell 1995, p.105)

In its depiction of the feminine within a male dominated institution, David Blaize subverts the hegemonic masculine ideal and invites the reader to take up an alternative subject position to that offered by the mainstream school story of the period. In the early part of the twentieth century, from the point of view of hegemonic masculinity, the potential for homo-erotic pleasure had been expelled from the masculine and located in a deviant group. Complex moral, legal and political questions around male sexuality abounded at that time. As Jeffrey Weeks points out, there was a medical and legal onslaught on homosexuality in Britain from the mid nineteenth century, which included the idea that masturbation was deemed to be a manifestation of unwholesomeness and unmanliness in the young, as well as a 'vice' associated with homosexuality (Weeks 1977 , pp.23-27). Moreover, the Labouchere Amendment to the
Criminal Law Amendment of 1885 made all homosexual acts illegal. This legislation criminalized all 'acts of gross indecency between males' with a penalty of up to two years imprisonment (Mort 1987, p.129 footnote 85). Aligned to this was the linking of the 'feminine' with physical weakness and the 'masculine' with strength and self-reliance. This paper examines the way that Benson manages to reinstate the feminine within the masculinist ideology/narrative ideologies that informed the narrative of the boarding school.

Hegemonic masculinity refers to those dominant and dominating forms of masculinity which claim the highest status and exercise the greatest influence and authority. It is culturally linked to both authority and rationality, key themes in the legitimation of patriarchy. In particular moments in history, ideologists of masculinity have attempted to control and direct the reproduction of masculinity. Attempts were made in the late nineteenth century to foster a particular masculinity amongst boys that of toughness, self-reliance, physicality and aggression.

It seems to me that late nineteenth/early twentieth century models of hegemonic masculinity are almost identical with the characteristics of those currently under debate in educational circles in connection with boys and violence. For example, Kenway and Fitzclarence assert that

At this stage of Western history, hegemonic masculinity mobilises around physical strength, adventurousness, emotional neutrality, certainty, control, assertiveness, self-reliance, individuality, competitiveness, instrumental skills, public knowledge, discipline, reason, objectivity and rationality. It distances itself from physical weakness, expressive skills, private knowledge, creativity, emotion, dependency, subjectivity, irrationality, co-operation and empathetic, compassionate, nurturant and certain affiliative behaviours. In other words it distances itself from the feminine and considers the feminine less worthy.

(Kenway \& Fitzclarence 1997, p.121)

Kenway and Fizclarence, suggest that 'hegemonic masculinity makes its claims and asserts its authority through many cultural and institutional practices', and its exclusive licensee or agent or by way of a licence from Copyright Agency Limited. For information about such licences contact Copyright Agency Limited on (02) 93947600 (ph) or (02) 93947601 (fax) 
that schools are implicated in the making of masculinities. Education plays a key role in the transformation of masculinity and a literature of the education of boys dates back to Dr Arnold whose educational philosophies influenced the sub-genre of novels about boarding school life of which David Blaize is a part.

R. W. Connell in Masculinities (1995) has also argued that contemporary pedagogy plays a key role in the transformation of masculinity. As well as asserting that the diversity of masculinities should be addressed in the curriculum, he suggests an approach that includes the feminine, so that boys will be enabled to take on board feminine viewpoints which, he says, are 'systematically denied in hegemonic masculinity' (p.239). One manifestation of hegemonic masculinity is violence. The connection of masculinity with violence is also a global connection. Connell attributes the change shift in hegemonic masculinity in Britain to one embracing more violent, aggressive characteristics - with the nineteenth century decline of the landowning gentry and the emergence of industrial economies and the bureaucratic institutionalization of violence.

In David Blaize, violence in the school setting is muted and obscured. But it is present, nevertheless in the manipulation of smaller boys by their seniors through sexual advances and predatory behaviour. In contrast, this violence is mitigated by the feminine space offered in the depiction of home: the friendship between the protagonists, David Blaize and Frank Maddox blossoms during the freedom they enjoy at Frank's seaside home in the holidays. Here verbal and physical expressions of affection can be freely given and reciprocated.

Kenway \& Fitzclarence advocate the use of narrative theory to offer both individuals and groups the opportunity to develop a new and alternative story-line to resist the dominant narrative. That is, they suggest that boys should be given the opportunity to talk out their feelings in order to identify alternative forms of masculinity. In my view homo-erotic novels such as David Blaize offered the early twentieth century reader an alternative model of masculinity, even if it is was in a coded and disguised form.

Passionate schoolboy friendships are vital ingredients of the English public school story, and are one strand in a definition of 'manliness'. Michael Rupert Taylor claims that nineteenth century schoolboy stories are 'one of the most significant discourses on male love of the period' (Taylor, M.R., 1999, p.7). What differentiates and illuminates David Blaize is an erotic subtext, highlighting a tension between sensuality and sexuality. Paradoxically, al though Benson's novel breaks new ground by exploring the emotional nature of boy friendships, the construction of its hero David as sexually innocent, reverts to the midnineteenth century didactic school story. Benson's subversive novel uses carefully coded language that provides a reading which invites readers to resist cultural codes and discourses around homosexuality and sexuality and is informed by late nineteenth and early twentieth century discourses of homosexuality and censorship. Such alternative reading positions play an important part in deconstructing notions of a hegemonic masculinity.

In discussing the role of friendships and how they are constructed in public school novels, I will analyse the way that the language in the text reveals gaps, since those textual contradictions and fissures are sites of conflict in cultural discourses and practices. The resistances and the various subject positions that readers are invited to take up in the text, provide indicators not only of the historically and socially constructed nature of the narrative, but also the fact that the production of a masculine 'ideal' involves exclusions.

A hegemonic masculinity existed in the late nineteenth century, the setting of this novel, which adhered to ideals of moral manliness stemming from the influential early Victorian educational philosophy of Dr Thomas Arnold. Amold equated manliness with intellectual energy, moral purpose and sexual purity. Davidoff \& Hall (1987) have shown that the expansion of capitalism alongside the rise of Evangelical religion prompted the growth of 'the new man' in the early years of the nineteenth century. John Tosh goes on to assert that masculinity now became defined by 'a punishing work ethic, independence of patronage or favour, piety and high-mindedness, sobriety and chastity, and dedication to family pursuits' (1991, p.46). From the 1830 s on, the public schools, which at that time catered for the sons of the aristocracy, adopted this new code of manliness. Arnold, Headmaster of 
Rugby School, aimed to raise the moral tone of the public schools and to do this he developed the moral in his boys alongside the intellectual. As John Tosh puts it, 'to be manly' was to put away boyish pursuits, and to grow up straightforward, earnest, and pure. Restless energy, a driving sense of duty, and an absence of frivolity were the marks of the true Arnoldian' (Tosh 1991). The public schools, under the influence of Arnold's philosophies, rapidly expanded to include the new middle class as well as the gentry.

However, Arnold was not the only influence on masculine ideals. Thomas Carlyle, for example advocated a much more 'muscular' style of manliness, where aggression and will-power took precedence over Christian virtues. Michael Roper and John Tosh claim that 'the juxtaposition of Arnold and Carlyle illustrates the variety of discourses about masculinity at a given time, but more importantly their uneasy and often unstable ordering in a gender hierarchy' (1991). Recent discussions have shown masculinity to be both an historical and a cultural construct. incorporating a variety of changing and competing forMs Roper and Tosh urge us to understand masculinities as subjective identity, as social power and as cultural representation. They suggest we should understand gender in relational terms, since dominant or hegemonic masculinities 'function by asserting their superiority over the "other". In the public schools, "manliness is defined through elaborate rituals in which supposedly feminine behaviour is ferreted out and lampooned' (Roper \& Tosh 1991, p. 13). And as Lynne Segal notes, masculinity refers to the effects of discursive practices, rather than any particular traits or stereotypical roles. Various types of discourses, according to Segal, 'set up' contradictory positions for women and men, and thus undermine any unitary or coherent sexual identities, while nonetheless providing sites for resistance and struggle (Segal 1990, p.92).

Contemporary constructions of knowledge about men and 'masculinity' have made it increasingly clear that all knowledge is socially produced. Alan Petersen in Unmasking the Masculine: 'Men' and 'Identity' in a Sceptical Age (1998) calls for additional analysis to address the power relations of sexuality and the ways in which heterosexual masculine identity became institutionalised as the ideal'. He claims that 'most research is taken as given, rather than problematiz[ing], the dominant epistemology of sexuality' (Petersen 1998, p.2).

Geoffrey Palmer and Noel Lloyd, in EF Benson: As He Was (1988), suggest that Benson's aims in writing David Blaize were allied to a wish to depict schoolboy friendships more realistically than they had previously appeared in print. That is, to include the strong emotional bonds between boys, as opposed to the typical school story, where the plot might focus on a cricket match, a mystery around the loss of a scholarship examination paper, and so on. As Palmer and Lloyd put it:

he wanted to write a story of school life that would be completely unlike Tom Brown's Schooldays, Tim or The Hill and the other traditional stories of bullies and cheats and captains of cricket who kiss the fevered brow of First Formers who are dying of consumption. He thought he could do it by depicting himself under the name of David Blaize as he really had been, or had wanted to be ... yellow-haired, sunny-natured and of an unbelievable goodness.

(1988, p.99)

On the one hand Benson's aim is subversive, in his treatment of adolescent male love. For example, the late Romantic poets Keats and Swinburne as well as the Uranian poets (who were interested in the aesthetic and spiritual appeal of adolescent boys and young men, and were associated with pederasty) are depicted as sources of inspiration and a catalyst for the friendship between the two schoolboy protagonists. Yet paradoxically Benson is also at pains to ensure that emphasis is laid on David's sexual innocence, and he hints that sensuality is not taken to be understood as synonymous with sexuality (at least not in its physical/homosexual expression).

The majority of school stories of the period of the late nineteenth/early twentieth centuries, whether written for children, or adults and children, ignore the sexual attraction between boys. They focus instead on platonic friendships. But Isabel Quigly reminds us that patterns of close friendships which is mirrored in the fiction, were (and 
probably still are to some extent), very much like those of courtship and marriage. She suggests that this may be why, 'to outsiders, the close friendships were perhaps the most wistfully regarded thing about it'. She states that pairing was 'an acknowledged part of school life, encouraged by all sorts of school arrangements - the sharing of studies, the need to have a regular companion for walks and having a 'best friend' was socially, emotionally, even practically necessary' (Quigly 1982, pp.81-2). Certainly in the Spartan all-male institution where bathing was communal and the lavatories were without doors, privacy was almost non-existent. Hickson's text The Poisoned Bowl (1995) alerts us to the fact that 'the architects of schools frequently sought to maximize the difficulty of getting from one dormitory to another' $(1995$, p.28). At one stage at Eton a wooden bar was balanced on the top of the dormitory cubicles which would crash to the ground if any boy thought of climbing out, while in other schools each bed had its own partition, often lockable only from the outside, with a single key in the possession of the head boy or housemaster (pp.28. 29). Close friendships may have provided compensation and comfort, as John R. Reed comments:

What should have been character-building frequently seemed to be outright demolition. A lack of privacy leading to numerous varieties of unspeakable humiliation, and a continual surveillance producing curious insecurity, drove sensitive boys into themselves, the only place where they could find sanctuary from an ominously pervasive system of control.

(1964, p.63)

What is seen to be acceptable in cultural representations of friendships, shifts with discourses and ideologies over time. By the late nineteenth century, in socio-historical terms, a hegemonic masculine discourse of empire was in place. Accordingly, the passionate male friendships celebrated in school novels like Thomas Hughes' Tom Brown's Schooldays and F. W. Farrar's Eric, Or, Little By Little, had become morally suspect and undesirable, and emotionality in middle-class friendship between boys had been replaced by attitudes of the 'stiff-upperlip'. Claudia Nelson alerts us to the paradox whereby 'girlish boys,' once idealized, have come by the end of the century to be figures of contempt. As Nelson puts it, 'the mid-Victorian's hero is the late-Victorian's sissy' (1991, p.51).

However, by the time David Blaize was published in 1917, 'girlish boys' were back in fashion, promoted by the First World War in what Martin Taylor calls a "public taste for homoeroticism' $(1989$, p.20). Taylor claims that around this time the popularity of poets like Brooke, Sassoon and Oswald 'fed poems on male love to an unsuspecting public'. Taylor says that these poems publicly proclaim 'the unique physical tenderness, the readiness to admire openly the bodily beauty of young men, the unapologetic recognition that men may be in love with each other' $(1989$, p. 15$)$. He points to the erotic quality of public school romantic friendships in texts like David Blaize, Tim, Julian Home etc and suggests that they contributed to the emotional tone of First World War poetry. As I pointed out earlier, there were legal issues and inherent dangers in censorship to contend with. Taylor claims that:

If the trial of Wilde brought the irrefutable
existence of homosexuality to the attention of the
late-Victorian public, the psychologists of the
early twentieth century made a new generation
aware of the ambivalent impulses underlying
male comradeship.
(1995, pp.15-16)

Male love is celebrated in David Blaize and yet coded language is used to exclude any accusations of 'immorality'. The novel appeared on the market during the early part of the First World War to critical acclaim and was avidly read by soldiers in the trenches. As a homo-erotic text, it engages with discourses of sexuality in general and with homosexuality in particular. Key legislative Acts had an important impact on these discourses. Certain censorship issues affect the narration of the text and Benson's use both of satire and coded language are devices that both legitimize and mitigate his treatment of passionate public school friendships.

Discourses of masculinity and sexuality are areas pertinent to the English public school and its fiction. The Victorian era is often associated with silence and repression on the topic of sexuality in the private realm. However Nelson 
states that by the end of the nineteenth century, there was so much written about the subject that 'the discourse itself had become a subject for discourse' (Nelson 1989, p.527). Foucault suggests that power relations produce forms of subjectivity around institutional pressures repressing children's sexuality. He argues for example, that discourse around the question of children's sexuality and in particular of onanism (male masturbation), not only failed to eliminate the practice, but in fact it led to an increase in the sexualisation of childhood:

Educators and doctors combated children's onanism like an epidemic that needed to be eradicated. What this actually entailed. throughout this whole secular campaign that mobilized the adult world around the sex of children, was using these tenuous pleasures as a prop. constituting them as secrets (that is, forcing them into hiding so as to make possible their discovery), tracing them back to their source ... wherever there was a chance they might appear, devices of surveillance were installed; traps were laid for compelling admissions; inexhaustible and corrective discourses were imposed; parents and teachers were alerted, and left with the suspicion that all children were guilty.

(Foucault 1978, p.32)

The novel follows the life of the protagonist David Blaize at both his preparatory and his public school, from the age of thirteen to seventeen. It charts his friendship with Frank Maddox, an older pupil. In those formative years, David matures from a boy to a young man. His maturity does not follow a linear progression, as it tends to in so many other school stories (new boy moves his way up the school to sporting and/or academic achievement). Instead both boys reveal flashes of mature insight and selfknowledge at times, with these revelations occurring alongside episodes more typical of life in the conventional school story, creating more than one subject position for the implied reader.

The text addresses a dual audience of both adults and children. It is also a heavily ironic text, describing, for example, the teachers as well as the schoolboys ironically.

Mr Dutton was: a tall and ineffective young man, entirely undistinguished for either physical or mental powers, who had taken a somewhat moderate degree at Cambridge, and had played lacrosse ... When the Sunday letters home were finished, Mr Dutton would read a chapter about the second missionary journey of St Paul, and then ask questions. But while these letters were being written Mr Dutton was not Sabbatically employed. for nestling between his books was a yellowbacked volume of stories by Guy de Maupassant ... Mr Dutton found him most entertaining: he skated on such very thin ice, and never quite went through.

(Benson 1917, pp.3-4)

Ironic observation of human activity was common in nineteenth century novels, but comparatively rare in fiction for children. The dual audience is implicit in the book's marketing. The front cover illustration of the 1989 paperback Hogarth Press edition of the novel shows a school cricket match, with the backdrop of a public school, complete with chapel and clock tower. Three schoolboys sit at a table drinking lemonade with striped blazers over their cricket 'whites'. The colourings are watercolour outlined in pen and ink, similar to illustrations in children's books of the period. The publisher's blurb on the back cover describes it as a 'nostalgic classic of public school life ... evoking the joys and torments of boyhood, from midnight feasts and glorious days on the cricket field to waxy masters and hilariously embarrassing parental visits...'. However, the Preface by Peter Burton, while describing it as 'a very jolly read' (his italics) makes mention of the fact that 'Benson moved in homosexual circles'. He goes on to say that 'there is no evidence that he ever fulfilled his emotional leanings; in fact the number of spinsters of both sexes in his many books suggests that he was without carnal knowledge, a knowing innocent' (Burton 1989, Introduction to Blaize 1917). This tension between innocence and knowledge underscores the novel. There is also, I argue, a third possible position for a reader, that of the possibility of decoding the erotic subtext.

The first six chapters of David Blaize are set at David's preparatory school, Helmsworth, where the daily routine 
and preoccupations of small schoolboys are described in great detail. For example, David keeps two stag-beetles as 'pets' in a 'cardboard travelling-carriage'. They live alternately in his locker, or in his desk, or in his trouser pocket. The welfare of the beetles preoccupies a great deal of David's time:

The lady was lying on her back, as good as gold, waving her legs slowly in the air, having probably fallen down on some climbing expedition about the roof of the locker, but the stag himself (called 'The Monarch of the Glen') could not at once be found. But a little careful rummaging disclosed him sitting morosely in a crevice between a grammar and a geography book.

'I say, I don't believe the Monarch's well,' said David.

'Shouldn't think so, living in your fuggy desk, ' said Bags, strolling out of the room.

(p.21)

David's unusual 'pets', are not just insects, in David's estimation. They take on anthropomorphic qualities, are gendered, and their behaviour described as if they were a heterosexual couple, capable of producing children ('babies'):

They were male and female, as the lady's absence oflong horns testified, and it was hoped that even in confinement she might some day be confined. Indeed, there were several bets on, as to which form the babies would take - whether they would be eggs, or some sort of caterpillar, or minute but fully developed stag-beetles.

(p.20)

At the same time that this narrative entertains a young audience with its description of class room and extracurricular life at boarding school, there are coded and suggestive phrases. In the double-entendres and sexual innuendoes of such phrases in the incident above, such as 'the lady was lying on her back', and 'a little careful rummaging,' and 'his attention was completely diverted by the feeling of a slight vibration in his trouser-pocket, caused by the movements of the Monarch and his wife...', we are led from the outset to understand David to be ignorant of biological function and naive about his own sexuality and that of his fellow students. His "white innocence' leading to 'boy-love, hot as fire and clean as the trickle of ice-water on a glacier' as described by Maddox (p.201), is a central theme of the novel. In other school novels published some fifteen to twenty years before David Blaize, references to sexual matters are often ignored, or veiled in language that obscures rather than illuminates. As Gillian Avery puts it, "it was the manly hero with his 'frank, open face', who mattered, generally speaking, in school fiction' (1965, p.145).

The narrator of F W Farrar's Eric, Or, Little By Little (1858) for instance, puts vice and virtue in opposition:

\begin{abstract}
Now, Eric, now or never! Life and death, ruin and salvation, corruption and purity, are perhaps in the balance together, and the scale of your destiny may hang on a single word of yours. Speak out, boy! Tell these fellows that unseemly words wound your conscience; tell them that they are ruinous, sinful, damnable; speak out and save yourself and the rest. Virtue is strong and beautiful, Eric, and vice is downcast in her awful presence.

(p.82)
\end{abstract}

But eventually, as stag-beetles gradually lose their appeal, David develops different passions. His artistic sensibility emerges at Helmsforth and develops alongside his friendship with Maddox. The Headmaster, Mr Acland, gives stirring sermons and in his English classes David is enchanted by his rendition of a Keats poem:

Keats's poem was part of the whole joy of life, it, and its music, and the sense of longing for something he did not know about, which it produced in him.

(p.93)

Attempting to articulate this feeling, David likens it to 'something he had felt once when he woke early and heard the chirruping of birds before daybreak...' (p.80). Acland's sermons and poetry elicit in David a physical response, suggesting sexual innuendo and even sexual climax: 
He began in tones so low that it needed an effort to hear him; it boomed out over 'charioted by Bacchus and his pards'; it sounded like a breeze at night in the stanza'I cannot see what flowers are at my feet'; again it shook with emotion over the 'sad heart of Ruth', and David felt a lump rise in his throat. a mysteriously blissful misery took possession of him. And when the Head finished he found himself smiling at him with a mouth that trembled a little.

(pp.93-4)

Benson's choice of the Romantic poet Keats as inspiration for David, is interesting on two counts. Keats was, like Benson himself, critical of dominant attitudes in his period in relation to literature and sexuality. There are ambiguities in Keats's own treatment of sexual love, reflecting divisions in his own psyche as well as that of his society. Secondly, the poem that Acland, the Headmaster reads, 'Ode to a Nightingale', is imaged on pure sensation. It is both sensuous and melancholy and strives to replicate moments of ecstasy. The Headmaster, in a private conversation, hints at another, dangerous side of public school life:

There are worse things than smoking, ...even worse things than stealing, and that many quite good chaps, as you would say, don't think there is any harm in them. There are worse things than stealing... Things that damn the soul, David. (p.115)

Benson's text is hardly more illuminating on the subject of homosexuality than Farrar's Eric, but the narrator's ironic tone allows the joke to be shared with the implied adult reader. An erotic tension continues to develop between the two boys, David and Maddox. Their relationship is constructed more like a romance between an adolescent boy and girl - departing from the textual construction of friendships in most school stories.

David and Maddox's friendship at school develops in a covert fashion, since Maddox is eighteen and David only fifteen and friendships between older and younger boys were discouraged. However, since Maddox is a Prefect he devises a stratagem that places David in the adjoining bed to his in the boarding house - allowing furtive conversations to take place between the boys.

When David is invited to stay at Maddox's beachside home at Naseby in the holidays, their relationship blossoMs The two boys spend most of their time alone, unchaperoned. Maddox takes the opportunity to read the late Romantic poets to David. Significantly, Swinburne, like Keats, celebrates ecstatic feeling in his poetry and his erotic imagination leads him to explore in them sensuous love. The choice of the particular poem that Maddox reads to David, has coded sexual meaning, since underlying 'Atalanta in Calydon' are the philosophies of de Sade. This poem was written at a time when Swinburne became influenced by the philosophies of de Sade and in fact Swinbume had been interested in sado-masochism since his schooldays at Eton. David mistakes 'Atalanta' for the Greek goddess Atlanta and is bewildered by Maddox's teasing laughter at his mistake. Maddox comments, 'Oh, you're such a kid ... and I keep forgetting it' (p.190). In this episode the narrator appears to be making ironic and 'veiled comments over the heads of both the child reader and the adult reader (who might or might not be unaware of the sado-masochistic undertones of the Swinburnian poem).

The boys, during this holiday period, are inseparable, 'alone on the hot beach', swimming naked, and playing gold. Maddox makes what could be construed as sexual overtones to David:

Frank picked up a handful of the dry powdery sand and let it trickle gently into the gap of shin that showed between the end of his trousers and the beginning of his sock.

(p.187)

Although David retains his 'white innocence' he is clearly aware of the 'dangers' of such intimacy:

Then came trudges through sandy places, with breathless suspense to see whether the balls had carried the last of the bunkers ... would be found nestling in little, steep, bare hollows and bedevilled hiding-places. David, in especial. found himself frequently in amazing and awful places, of which Satan had certainly been the architect.

(p.197) 
Again, the coded language has the possibility of a doublemeaning for an adult or child readership. In David at King's, the book's sequel which follows David and Maddox's friendship through Cambridge University, the friendship increases its physical expression:

Frank shifted his position a little, and extended his hand round the back of David's neck.

We've loved each other, thank God; I've been first in your life, and you in mine.

(Benson 1924, pp.302-3)

But at school, Maddox, who ironically has David as his 'fag' (a younger boy who does the domestic chores), takes on the role of protector of David's sexual innocence, but is clearly tempted to move the relationship to a physical level. The scene that illustrates this tension between sexuality and sensuality is one that is focalised through both David and Maddox. David returns to school from a walk into town in the rain, and is soaked to the skin. He gets into a hot bath and is sitting naked on the edge of the bath drying himself when Maddox looks in:

There, on the end of the bench below the steamclouded windows, was David sitting, his head enveloped in a towel, violently scrubbing, and whistling whenever the towel was not in actual contact with his mouth. He had not noticed his entry, and Maddox thought it would be rather amusing to sit down without speech close beside him, holding out, in mute reproach, the empty kettle that David should have filled. This he did. (p.146)

There is something in Maddox's expression, that unsettles and puzzles David and after a short conversation between the two boys, the focalisation switches to David:

David paused. There was Maddox only looking at him, only smiling. But instantly he had some sense of choking discomfort. He looked back at him. frowning and puzzled, and his sense of discomfort hugely increased. He merely wanted to get away.

'Othen. I think I'll goand dress, ' he said hurriedly, and, picking up his sponge, left the room and ran away down the dark passage to his dormitory.

David sat down on his bed for a minute, feeling as if he had escaped from some distant nightmare that vaguely threatened to come near him. (p.146)

Maddox hurriedly leaves the bathroom, and the reader realises that he had come perilously close to moving the friendship to a different level:

Maddoxhad gone straight backfrom the bathroom
to his study, without filling his kettle. He sat for
ten momentous minutes infront of his fire without
doing anything. All these weeks that intense
friendship which was springing up between
himself and David had been splendidly growing,
and till now his influence over him had been
exerted entirely for David's good. He had
constantly shielded him, as on the night when he
had found Hughes sitting on his bed, from all that
could sully him, he had checked any hint of foul
talk in David's presence, for, of all his lovable
qualities, there was none so nobly potent to the
elder boy than David's white innocence, his utter
want of curiosity about all that was filthy. It
didn't exist for him, but the danger of it (though,
thank God, it had passed) he knew that he himself
had brought near to him...Then he got up and
looked at himself in the mirror above his
mantelpiece, hating himself.

'You damned beast,' he said: 'You deserve to be shot.'

(pp.148-9)

The choice of the word 'beast' refers to 'beastliness', the schoolboy slang term for the physical expression of homosexuality. David, for his part, is alarmed that he has narrowly escaped from something that he cannot quite articulate. Brian Masters, Benson's biographer, says that in the original manuscript the scene in the bathroom is more graphically described. It has Maddox coming so close to the naked David that their skin touches. Masters says that the first version of the story 'is altogether more tactile' and that the episode is 'unquestionably a love scene' (Masters 1991, p.76). A short while after the 
bathroom incident, Frank beats David for cribbing. After the beating, David feels momentarily unwell and the following paragraph, focalised through David, can be construed as a moment of ecstasy:

There was a sudden singing in his ears, and Maddox caught him as he reeled, and put him gently down into a chair, as he leaned on him. But David's faintness was only momentary, and, recovering, almost instantly, he saw that Maddox was looking almost as queer as he himself felt. (p.167)

The ambiguities around the expression of 'boy-love' between David and Maddox is perhaps symptomatic both of other divisions in place in late-Victorian and Edwardian society about sexuality and Benson's own uneasiness about the relationship between sensuality and sexuality. Lastly, there is confusion underlying the policies of the schools themselves. Peter Parker, in writing about the First World War and the public school ethos, sums up these conflicts with this observation:

They insisted upon attempting to differentiate between what they saluted as the highest of all affections, which led to panegyrics in the chapel, and what they called 'beastliness', which generally led to expulsion.

(Parker, 1987, p. 107)

David Blaize is subversive, and sets out to clarify some of these questions, even though it appears to be as reticent as its mid-nineteenth century school story counterpart in its evasions on the subject of expressions of affection in male friendship. It does offer an alternative reading position and model of masculinity which resists hegemonic masculinity by including 'feminine' values in its version of masculinity. But as Kenway and Fitzclarence note, there is still a long way to go in working out a pedagogy where:

males and females, males and males and adults and children can live alongside each other in safe, secure, stable, respectful and harmonious ways in relationships of mutual life-enhancing respect.

(1997, p.132)

\section{REFERENCES}

Avery, Gillian (1965) Nineteenth Century Children: Heroes and Heroines in English Children's Stories 1780-1900. London, Hodder \& Stoughton.

Badinter, E. (1995) in Petersen, Alan (1998) Unmasking the Masculine: 'Men' and 'Identity' in a Sceptical Age. London, California \& New Delhi, Sage Publications.

Benson, E.F. (1924) David at King's. London, Hodder \& Stoughton.

Benson, E.F. (1989) David Blaize, with New Introduction by Peter Burton. London, The Hogarth Press.

Connell, R.W. (1995) Masculinities. Sydney, Allen \& Unwin.

Davidoff, Leonore \& Hall, Catherine (1987) Family Fortunes: Men and Women of English Middle Class 1780-1850. Chicago, University of Chicago Press.

Deakin University Study Guide ALL201. Romanticism,(1997), Geelong.

Farrar, Frederick W.(n.d.) [1858] Eric, Or, Little by Little: A Tale of Roslyn School. London. A\&C Black.

Foucault, Michel (1978) The History of Sexuality: An Introduction, Vol. 1. Harmondsworth, Penguin.

Hantover, Jeffrey P. (1978) 'The boys scouts and the validation of masculinity', Journal of Social Issues $3,1$.

Henderson, Philip (1974) Swinburne: The Portrait of A Poet. London, Routledge \& Kegan Paul.

Hickson, Alisdare (1995) The Poisoned Bowl: Sex, Repression and the Public School System. London, Constable.

Kenway, Jane \& Fitzclarence, Lindsay (1997) 'Masculinity, violence \& schooling: Challenging "poisonous pedagogies", Gender and Education 9, 1. 
Kimmel, M.S. (1997) in Petersen, Alan (1998) Unmasking the Masculine: 'Men' and 'Identity' in a Sceptical Age. Sage Publications, London, California \& New Delhi.

Masters, Brian (1991) The Life of E.F. Benson. London, Chatto \& Windus.

Mort, Frank (1987) Dangerous Sexualities: Medico-moral politics in England since 1830. London \& New York, Routledge \& Kegan Paul.

Nelson, Claudia (1991) Boys Will Be Girls: The Feminine Ethic \& British Children's Fiction, 1857-1917. New Brunswick, New Jersey, Rutgers University Press.

Nelson, Claudia (1989) 'Sex and the single boy: Ideals of manliness and sexuality in Victorian literature for boys', Victorian Studies, Summer.

Palmer, Geoffrey \& Lloyd, Noel (1988) EF Benson: As He Was. Luton, Lennard Publishing.

Parker, Peter (1987) The Great War and the Public-School Ethos. London, Constable.

Petersen, Alan (1998) Unmasking the Masculine: 'Men' and 'Identity' in a Sceptical Age. London. Thousand Oaks California, New Delhi, Sage Publications.

Quigly, Isabel (1982) The Heirs of Tom Brown: The English School Story. London, Chatto \& Windus.

Reed, John R. (1964) Old School Ties: The Public Schools in British Literature. New York, Syracuse University Press.
Roper, Michael \& Tosh, John (1991) Introduction to Manful Assertions: Masculinities in Britain since 1800. London \& New York, Routledge.

Segal, Lynne (1990) Slow Motion: Changing Masculinities Changing Men. London, Virago Books.

Taylor, Martin (1989) Lads: Love Poetry of the Trenches. London, Constable.

Taylor, Michael Rupert (1999) 'Homosexuality and boys' school stories in the 1960s,' in Nicholas Tucker (ed) NCRCL Paper 4: School Stories From Bunter to Buckeridge. National Centre for Research in Children's Literature.

Tosh, John (1991) 'Domesticity and manliness in the Victorian middle class: The family of Edward White Benson', in Michael Roper \& John Tosh (eds) Manful Assertions: Masculinities in Britain since 1800. London \& New York, Routledge.

Weeks, Jeffrey (1977) Coming Out: Homosexual Politics in Britain, from the Nineteenth Century to the Present. London, Melboume, New York, Quartet Books.

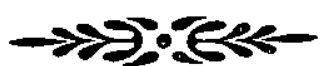

\section{BIOGRAPHICAL NOTE}

Carol Naylor currently teaches at Deakin University, where she is also doing her Ph.D.

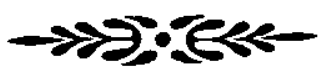

